\title{
A NEED ANALYSIS ON CHARACTER-BASED CAMPUS TELEVISION TO SUPPORT THE INTEGRATED LABORATORY OF LEARNING TECHNOLOGY
}

\author{
Sunaryo Soenarto \\ Department of Electrical Engineering Education, Faculty of Engineering, Universitas Negeri Yogyakarta \\ E-mail: sunaryos@uny.ac.id
}

\begin{abstract}
The role of Campus Television (TV) in a university can integrate human resources and audio visual laboratory facilities in each faculty, especially to face today's digital communication era. The objectives of this study were: (1) to determine the academic community's needs for Campus Television media in Universitas Negeri Yogyakarta (UNY) based on faculties, and the academicians status and (2) to map program types broadcasted by the Campus TV in UNY that were expected by UNY academic community. A survey to the academic community in UNY (consisted of lecturers, employees, and students) was conducted as the research method. Electronic-based questionnaires and smartphones with Google form applications were used as the technique in the data collection. The research subjects were 409 respondents. The data analysis technique was descriptive quantitative. This study concluded that (1) lecturer who agreed and doubted about the existence of Campus TV in UNY were $97.33 \%$, and $2.66 \%$ respectively; (2) Employees who agreed was 100\%; and (3) Students who agreed, doubted, and disagreed about the existence of Campus TV in UNY were $92.63 \%, 6.31 \%$, and $1.02 \%$ respectively. Campus TV broadcasting programs required by the academic community in UNY included: (1) innovative work programs, (2) campus information, (3) campus activity programs (community service, teaching practice, conference), (4) talk show and (5) skills program. This study provided encouragement to academic community of UNY to support the realization of Campus TV as the integrated laboratory for learning technology.
\end{abstract}

Keywords: academic community, campus television, learning technology

\section{INTRODUCTION}

Minister of Research, Technology and Higher Education, Muhammad Nasir, hopes that state or private universities become the seedlings of professional media workers. During the campus television inauguration of Indonesia Art Institute of Padang Panjang, He said that universities should create qualified human resources in the field of television because the national competitiveness can only be realized with creative or qualified workers. Since television media is gaining increasing importance and recognition among the corporate world for message communication and promo propaganda [1]. In line with this, Chassiakos, et al. [2] reveal that though people now have access to a wide variety of other media beyond television, television is still the most accessible screen-based medium and television viewing times remain high. It still has strong effects on several aspects of human life. Elaborating on the negative effect of television, Apuke [3] asserts that in recent times, it has been observed that a change is occurring in the mode of dressing and clothing style of the younger population. Similary, Okeoma [4] conducted a similar study, on the influence of home movies on the dressing patterns of students of tertiary institutions in Abia state, notes that home movies mediate in the culture of students of tertiary institutions in Abia state especially as it relates to their dressing patterns. In addition, the problem of 
violence on television and its impact on behavioral aggression of the audience is also becoming the issues in media effects [5].

Research has shown that movies, like books, are important medium of cultural transmission and socialization. Hameed et al. [6] added that TV advertisement impact on buying behavior due. Even, television in particular has been found to impact outcomes as diverse as voter turnout in social capital in Indonesia [7]. Jahangir \& Nawaz [8] has also explored the impacts of television as an information source with special regard to its audience's mental health.

This condition urges the existence of Campus TV that can provide positive values among society. Campus TV as an audiovisual media is the dominant communication medium for students to obtain an overview and image of the social reality about campus activities since television is an effective tool in expressing abstract concepts or ideas [9]. It presents campus values and character which is integrated with news and entertainment. Soenarto [10] supports that television media is basically utilized as a communication medium in which audience pay more attention to the production results of the television program, rather than the intrinsic values contained in the various programs of campus television. Young viewers watch television as a way of wishful identification and therefore, prefer television portrayals [11].

In line with this, Apuke \& Dogari [12] mention that since television came into existence, it has remained the most influential medium among the mass media and it can be considered a credible source of information. Television has significant role in developing the social values, ideas, attitudes, lifestyle [13] and moral development [14].

Broadcasting Law No. 32/ 2002 [15] describes that the community has the opportunity to take part in television broadcasting. This positive intention from the government was realized by establishing a Community Broadcasting Institution. It is the legal broadcasting institution for specific communities which is independent, noncommercial, low transmittance, limited regional coverage, and it is to serve based on the community's interests. As for streaming, it has wide-range coverage.

Campus TV can plan and produce their programs independently according to the campus characters. As found by Baydar et.al [16] that television can have the potentially influential role of non-formal education in promoting cognitive development. It shows the potential of campus tv for delivering full local content in order to develop the character of creativity, and independence, Further development is undoubtedly expected that TV campus can also produce or deliver materials using mechanical and electronic machines to present audio and visual messages [17]. More recently, cell phones are allowing users access to a variety of entertainment options at their fingertips. This merging of technologies offers opportunities for college students to further adapt media offerings to their needs and desires [18] . Campus TV is also expected to teach the students to become reliable and professional television broadcasting personnels. Campus TV provides a laboratory of creativity and production to learn how to produce simple television programs [19]. Campus TV can be also considered as media for the university to promote the vision and mission and to communicate with the community. 
Therefore, this study is expected to contribute to the development of campus TV in Universitas Negeri Yogyakarta.

This study aimed at (a) determining the needs for campus tv among academic community in Universitas Negeri Yogyakarta (UNY) in terms of conventional broadcasting and streaming based on faculties, and academician status, and (b) revealing the types of conventional broadcasting programs and streaming programs that are expected by the community of UNY. In this digital era, campus television with streaming format become an effective communication medium among students and academic community. It is crucial to reinforce the management to realize campus TV of UNY television as the integrated laboratory for learning technology.

Malaysia has developed Pusat Perkhimatan Persebaran Pendidikan (PPPP) since 1972. This education broadcasting unit is directly responsible to the prime minister under the supervision of the Minister of Teaching. Meanwhile, Indonesia began its education TV in 1979 with the establishment of Pusat Teknologi dan Komunikasi (Pustekkom), or Technology and Communication Center, under the guidance of the Minister of Education and Culture. Pustekkom in 1982 received project assistance from USAID to complete production facilities for various electronic media software (audio, film, and television recording) that met the broadcasting standards [20].

On August 31, 1999, the students of Institut Teknologi Bandung, Indonesia established Ganesha Televisi (GTV). GTV as a television campus community had peaked in 2002-2003. After that, GTV has suffered a setback since the sealing by the Department of Communication and
Information due to its illegal broadcasting. $\mathrm{Ki}$ Supriyoko explained the existence of television within a campus environment, is part of electronic media, but campus television usually receives little attention from to the public. The audience is already "bored" with the existing television programs that mostly lack educational aspects. Campus television can be an alternative for educational content. The Minister of Education and Culture, Muhammad Nuh, had permitted campus tv as a television of education.

Currently, the development of campus television has been in a consolidation era of strengthening the status of campus tv. On March 17, 2017, located in Universitas Multimedia Nusantara (UMN), it was held the Declaration of Indonesian Campus Television Association. This declaration was attended by 12 Indonesian television campuses consisting of UMN TV, DNK TV, FIVE TV, Bandung OK TV, UAD TV, Budiluhur TV, SIGMA TV, UNTIRTA TV, MMTC TV, UPN Television, Suka TV, and UNHAS TV [14].

The Broadcasting Law No. 32 of 2002 implicitly explains that campus $\mathrm{TV}$ is categorized as a community television broadcasting institution. Reinforced by Government Regulation No. 51 of 2005 article 2, it emphasizes that Community Broadcasting Broadcasting Institution is established by the community (can be interpreted as UNY academic community) in certain areas, which is independent, noncommercial, low transmittance, limited coverage and only for the community interests.

The production of campus tv programs has a variety of broadcast formats and materials. Some formats often have different production visions. The television broadcasting program of UNY campus has a 
vision for being a great, creative, and innovative educational university based on piety, autonomy, and intellectuality. Thus, the character of excellent, creative, innovative, pious, autonomous, and intellectual become the spirits in developing the broadcasting programs. Moreover, during the program production, it can also be the students' source of learning in order to develop aspects of character building or soft-skills, such as cooperation, respecting opinions, sense of belonging, responsibility, honesty, and willingness to sacrifice [21].

Wibowo [22] described that various public television programs covering cultural arts, television religion, news, documentary, feature, magazines program, sport, reporters. Darwanto [23] analyzes the relevant broadcast formats to campus TV, such as religion, reports (news), interviews, discussions, dialogues, highlights, student voice of vox-pop, entertainment, skills programs, and learning models. The television broadcasting program of Widyatama University, Bandung has the broadcast formats as follows: $20 \%$ for campus info, $20 \%$ of main profiles and faculty, $40 \%$ for entertainment/music/ fruit presentation works, religion info of $10 \%$, and $5 \%$ for an interlude as well as weekly info respectively.

Although campus television as a form of community television broadcasts has a short broadcasting range, digital broadcasts (streaming) with the broader coverage have not been regulated in the Broadcasting Law No. 32 of 2005. This was confirmed by the Expert Staff of the Ministry of Communication and Information that campus television with the development of the internet can be considered a global TV, no longer as community TV. It means campus TV that has broadcasted online does not have a legal status yet since the government has not regulated yet and campus TV streaming is not part of Broadcasting Law. Therefore, this research takes a role as the stimulus and reinforcement step for the university management to realize campus UNY television as the integrated laboratory for learning technology.

\section{METHOD}

This study was a survey study with The subject of the study consisted of lecturers, staffs, and students in UNY. These three groups were the main viewers of UNY campus television. They are the most familiar parties with the expectations and needs of the UNY campus TV program. The research period was one month, from April to May 2018. Research settings were seven faculties, two institutions, and technical implementation units of UNY. The sampling technique was done randomly. The multistage techniques were carried out by: (1) identifying the number of students, staffs, and lecturers in UNY, (2) determining the number of samples for students, staffs, and lecturers proportionally as well as implementing units, (3) determining the number of samples per faculty and work unit through purposive sampling based on Krejcie \& Morgan [24]. Until the end of the research implementation, the proportional aspects cannot be achieved. The data of the research subjects involved the sample of 60 lecturers, 32 employees, and 317 students. Table 1 presents the population and research sample. 
Table 1. Population and Research Sample

\begin{tabular}{lcccccc}
\multicolumn{1}{c}{ Faculty } & \multicolumn{3}{c}{ Research Population } & \multicolumn{3}{c}{ Research Sample } \\
& Lecturers & Staff & Students & Lecturers & Staff & Students \\
\hline Educational sciences & 190 & 100 & 5.166 & 10 & 5 & 52 \\
Languages and arts & 216 & 85 & 6.164 & 11 & 5 & 62 \\
Mathematics and sciences & 197 & 85 & 3.804 & 10 & 5 & 39 \\
Sport sciences & 117 & 80 & 4.067 & 6 & 4 & 41 \\
Social sciences & 93 & 57 & 2.895 & 5 & 3 & 29 \\
Engineering & 255 & 130 & 5.851 & 13 & 7 & 59 \\
Economics & 100 & 49 & 3.418 & 5 & 3 & 35 \\
Total & 1.168 & 1075 & 31.365 & 60 & 32 & 317 \\
\hline
\end{tabular}

The needs analysis instrument was developed covering five aspects as mentioned in Table 2. To gain extensive samples, the Google form application was used. The research questionnaire was sent to the respondents through WhatsApp application and email@uny.ac.id .

The data collection technique used the questionnaire with Linkert scale format and it had been validated by two media experts. The trial was then carried out and obtained the validity of 0.798 , reliability of 0.812 , respectively. It means that the research instruments were appropriate to be used.

Table 2. The Research Instrument Guidelines

\begin{tabular}{clc}
\hline No & \multicolumn{1}{c}{ Aspects } & Item \\
\hline 1. & Campus policy & 3 \\
2. & The Academic Community & 5 \\
& Characteristics & \\
3. & Technology Development & 4 \\
4. & Resource Development & 4 \\
5. & Campus TV Programs & 12 \\
\hline
\end{tabular}

\section{RESULTS AND DISCUSSION}

The research subjects consisted of students, staffs, and lecturers. The number of respondents was 245 people representing 7 faculties and working units. The sample distribution consisted of the lecturers with 75 people (30.6\%), the students with 126 people $(51.4 \%)$, and the staffs with 44 people $(18.0 \%)$. The sample distribution had already represented the opinions of the academic community.

This study is the initial stage of milestones development research of UNY campus television. The need analysis for the presence of campus television showed that as a whole. In a short period of time (one month), the study gained the response from 409 respondents. Respectively, the number of samples included lecturers $5 \%$ employees $3 \%$ and students $1 \%$ of the total population group. The results showed that the academic community agreed with the average score of $96.65 \%$. The parties who expressed doubt was as many as $4.49 \%$, and the disagreed one was $0.51 \%$. The following table presents the data in details.

Table 3. Data on Academic Community Opinion

\begin{tabular}{cccc}
\hline Opinion & Students & Staff & Lecturers \\
\hline Agree & 92.63 & 100 & 97.33 \\
Doubt & 6.31 & 0 & 2.66 \\
Disagree & 1.02 & 0 & 0 \\
\hline
\end{tabular}

Based on the distribution above, it was clear that the academic community were very enthusiastic about the presence of traditional and streaming broadcasting television. Even, the staff had an absolute 
need for the presence of campus television. It means none staff expressed doubts or refused the presence of Campus TV. The lecturers were also strongly support the campus TV (97.33\%) as the learning technology laboratory that can be able to integrate the audio-visual studios in several faculties. Of the student groups, 92.63\% stated strongly agree for the presence of campus TV as the integrated laboratory, with the variety of broadcasting programs to synergize various students' potential. Only small portion of students disagreed and doubted, i.e. $1.02 \%$ and $6.31 \%$, respectively and those require further investigation.

The existence and sustainability of campus television programs were very much determined by the viewers' interest in the programs. For this reason, the production of campus television broadcasting programs must be based on the needs of the academics community. The five broadcasting programs that were needed UNY academic community include (1) innovative works, (2) campus surrounding, (3) campus activity programs (community service, teaching practice, conference), (4) talk show, and (5) skills program.

\section{CONCLUSIONS}

The need for UNY Campus Television based on the opinions of UNY academic community can be concluded as follow (1) $97.33 \%$ of lecturers agreed, and $2.66 \%$ expressed doubt, (2) $100 \%$ of employees agreed, (3) $92.63 \%$ of students agreed, $6.31 \%$ expressed doubt, and $1.02 \%$ showed disagreement, (4) Five broadcasting programs that are needed by the community of UNY academics, included: (1) innovative works, (2) campus information, (3) campus activity programs (community service, teaching practice, conference), (4) talk show, and (5) skills program. It is recommended that Faculty of Engineering can be the pioneer and visionary to coordinate to the university level in realizing: (1) Campus television as community television, and (2) LPPMP audio-visual laboratory as a joint-laboratory for audiovisual media practice among several relevant study programs in UNY. The existence of university-level audiovisual laboratories can be designed as a laboratory that integrates the superior character of UNY with various learning outcomes, especially for the relevant courses such as audiovisual communication, audiovisual media production, and television program production. Moreover, campus television can be developed into streaming-based TV as an effective communication medium for producing, managing, and distributing messages, activities as well as university programs. It should also involve lecturers, students, and staffs in producing conventional and digital streaming television programs.

\section{REFERENCES}

[1] P. Baskaran and S. Pragadeeswaran, "Economies of Television Media and its RFI Targeting Luxury Segment," Procedia - Soc. Behav. Sci., vol. 37, pp. 207-216, 2012.

[2] Y. (Linda) Reid Chassiakos, J. Radesky, D. Christakis, M. A. Moreno, C. Cross, and COUNCIL ON COMMUNICATIONS AND MEDIA, "Children and Adolescents and Digital Media," Pediatrics, vol. 138, no. 5, p. e20162593, Nov. 2016.

[3] A. D. Oberiri, "Western Films and Youth Dressing Pattern in Nigerian Tertiary Institutions," Int. Aff. Glob. Strateg., vol. 48, no. 0, pp. 18-24, 2011.

[4] F. C. Okeoma, "A Study of the Influence of Home Movies on The 
Dressing Patterns of Students of Tertiary Institutions in Abia State," University of Nigeria, 2012.

[5] Y. D. Havrylets, V. Rizun, S. Tukaiev, and M. Makarchuk, "Methodology to Study Behavioral Aggression Due to the Impact of Television Programs," Curr. Issues Mass Commun., no. 17, pp. 8-21, 2015.

[6] A. Hameed, A. Waqas, M. N. Aslam, M. Bilal, and M. Umair, "Impact of TV Advertisement on Children Buying Behavior," Int. J. Humanit. Soc. Sci., vol. 4, no. 2, pp. 246-261, 2014.

[7] B. A. Olken, "Do Television and Radio Destroy Social Capital? Evidence from Indonesian Villages," Am. Econ. J. Appl. Econ., vol. 1, no. 4, pp. 1-33, Sep. 2009.

[8] S. F. Jahangir and N. Nawaz, "Effects of Television on Mental Health," FWU J. Soc. Sci., vol. 8, no. 1, pp. 97-107, 2014.

[9] Saglik, "Television as An Educational Technology: Using Television At Open Education Faculty, Anadolu University," Turkish Online J. Distance Educ., vol. 2 , no. 1, 2001.

[10] S. Soenarto, "Televisi Komunitas UNY (TVKU UNY) untuk Pemberdayaan Civitas Akademika," J. Ilm. WUNY, vol. 18, no. 2, Jul. 2016.

[11] K. Boehnke, T. Münch, and D. Hoffmann, "A German Study on the Use of Radio in Adolescence," Int. J. Behav. Dev., vol. 26, no. 3, pp. 193201, May 2002.

[12] O. D. Apuke and K. A. Dogari, "Influence of Television Programmes on Youth Dressing Pattern in Nigerian Tertiary Institutions," J. Int. Relations, Media Mass Commun. Stud., vol. 3, no. 2, pp. 32-45, 2017.

[13] Kanika and J. Kaur, "Media as an Agent of Iculcating Values: A Truth or A Myth?," Int. J. Educ. Res. Technol., vol. 7, no. 1, pp. 1-4, 2016.
[14] D. Singh, "Television Viewing Habits and Moral Formation of Childrenin Rural India," J. Humanit. Soc. Sci., vol. 19, no. 1, pp. 12-16, 2014.

[15] Republic of Indonesia, Law No 32 Year 2002 on Broadcasting. 2002.

[16] N. Baydar, Ç. Kağitçibaşi, A. C. Küntay, and F. Gökşen, "Effects of an Educational Television Program on Preschoolers," J. Appl. Dev. Psychol., vol. 29, no. 5, pp. 349-360, Sep. 2008.

[17] M. Munir, "Analisis Pengembangan Media Pembelajaran Pengolah Angka (Spreadsheet) Berbasis Video Screencast," J. Pendidik. Teknol. dan Kejuru., vol. 21, no. 4, pp. 307-313, Sep. 2013.

[18] K. J. Damratoski, A. R. Field, K. N. Mizell, and M. C. Budden, "An Investigation Into Alternative Television Viewership Habits Of College Students," J. Appl. Bus. Res., vol. 27, no. 1, Jan. 2011.

[19] F. Murfianti, "Perencanaan Strategis Pengembangan TV Kampus ISI Surakarta sebagai Televisi Seni dan Budaya," J. Penelit. Seni Budaya, vol. 6, no. 2, pp. 89-96, 2014.

[20] Y. Miarso, Menyemai Benih Teknologi Pendidikan. Jakarta: Prenada Media, 2004.

[21] D. Rahdiyanta, P. Hargiyarto, and A. Asnawi, "Characters-Based Collaborative Learning Model: Its Impacts on Students' Attitude and Achievement," J. Pendidik. Teknol. dan Kejuru., vol. 23, no. 3, pp. 227234, Apr. 2017.

[22] F. Wibowo, Dasar-dasar Produksi Program Televisi. Jakarta: Grasindo, 1997.

[23] D. S. Subroto, Produksi Acara Televisi. Yogyakarta: Duta Wacana, 1992.

[24] R. V. Krejcie and D. W. Morgan, "Determining Sample Size for Research Activities," Educ. Psychol. Meas., vol. 30, no. 3, pp. 607-610, Sep. 1970. 